\title{
Leaching potential and residual effect of amicarbazone in soils of contrasting texture
}

\section{Potencial de lixiviação e efeito residual de amicarbazone em solos de texturas contrastantes}

\author{
Ana Cássia Silva Possamai ${ }^{1}$; Miriam Hiroko Inoue ${ }^{2 *}$; Kassio Ferreira Mendes ${ }^{3}$; \\ Diogo Carneiro de Santana ${ }^{4}$; Ronei Ben ${ }^{5}$; Elielton Germano dos Santos ${ }^{5}$
}

\section{Resumo}

\begin{abstract}
A infestação de plantas daninhas é um dos principais fatores bióticos presentes no agroecossistema da cana-de-açúcar que têm a capacidade de interferir no desenvolvimento e na produtividade da cultura. O trabalho teve como objetivo avaliar o potencial de lixiviação e efeito residual do herbicida amicarbazone utilizado na cultura da cana-de-açúcar, em solos contrastantes. Para tanto, utilizaramse amostras de Neossolo Quartzarênico (NR - textura arenosa) e Latossolo Vermelho (LR - textura argilosa). No potencial de lixiviação, após a aplicação do herbicida amicarbazone (NR 1,05 kg ha-1 e LR 1,40 $\mathrm{kg} \mathrm{ha}^{-1}$ ), foram aplicadas lâminas de 0, 20, 40, 60, 80 e $100 \mathrm{~mm}$ de água nas colunas de solos. Avaliou-se o efeito residual, após a permanência do herbicida no solo de textura argilosa e arenosa, por períodos de 0,25, 50, 75 e 100 dias após a aplicação (DAA) de amicarbazone $\left(0 ; 1,05 ; 1,40 \mathrm{~kg} \mathrm{ha}^{-1}\right)$ nos tratamentos. $\mathrm{O}$ amicarbazone apresentou elevada lixiviação a partir da lâmina de $60 \mathrm{~mm}$ de água em solos de textura arenosa, constatando menor efeito residual. Em solo argiloso, lâminas de 20 a 80 $\mathrm{mm}$ de água reduziram a biomassa até a profundidade de $5-10 \mathrm{~cm}$, com o uso deste herbicida. Com base nos resultados, conclui que o amicarbazone apresentou elevada lixiviação e menor efeito residual em solo arenoso. O efeito residual do amicarbazone foi prolongado conforme o aumento do teor de argila e matéria orgânica presente no solo.
\end{abstract}

Palavras-chave: Impacto ambiental, mobilidade, persistência, retenção

\begin{abstract}
The infestation of weeds is a major biotic factor in the agroecosystem of cane sugar that may interfere in development and crop productivity. This study aimed to evaluate the potential for leaching and residual effects of the herbicide amicarbazone in contrasting soils. Samples were Quartzarenic Neosol (NR - sandy texture) and Red Latosol (LR - clay texture). For the leaching potential, after application of herbicide amicarbazone (NR $1.05 \mathrm{~kg} \mathrm{ha}^{-1}$ and LR $1.40 \mathrm{~kg} \mathrm{ha}^{-1}$ ), layers of 0, 20, 40, 60, 80 and $100 \mathrm{~mm}$ of water were applied to soil columns. We evaluated the residual effect after the permanence of the herbicide in soil of clay texture and sandy for periods of $0,25,50,75$ and 100 days after application (DAA) of amicarbazone $\left(0,1.05,1.40 \mathrm{~kg} \mathrm{ha}^{-1}\right)$ treatments. The amicarbazone started showing high
\end{abstract}

${ }^{1}$ Ph.D. candidate in Agronomy, Universidade Estadual de Maringá, UEM, Maringá, PR. E-mail: anacassiapossamai@hotmail.com

${ }^{2}$ Ph.D. Prof. from Universidade do Estado de Mato Grosso, UNEMAT, Tangará da Serra, MT. E-mail: miriamhinoue@hotmail.com

${ }^{3}$ Masters in Agronomy, Vegetable Production, Universidade Federal de Viçosa, UFV, Rio Paranaíba, MG. E-mail: kassio_ mendes_06@hotmail.com

${ }^{4}$ Masters in Agronomy, Universidade Estadual Paulista, UNESP/FCA, Faculty of Agricultural Sciences, Botucatu, SP. E-mail: diogopd@gmail.com

${ }^{5}$ Undergraduate student in Agronomy, UNEMAT, Tangará da Serra, MT. E-mail: roneiben@hotmail.com; elielton_germano7@ hotmail.com

${ }^{*}$ Author for correspondence 
leaching from the $60 \mathrm{~mm}$ layer of water in sandy texture soils, evidencing a shorter residual effect. In clay soil, slides from 20 to $80 \mathrm{~mm}$ of water reduced the biomass until a depth of 5-10 cm, with the use of this herbicide. Based on these results, we conclude that the amicarbazone showed higher leaching and lower residual effects in sandy soil. The residual effect of amicarbazone was prolonged as the content of clay and organic matter present in the soil increased.

Key words: Environmental impact, mobility, persistence, retention

\section{Introduction}

Negative interference imposed by weeds is one of the main critical factors limiting the potential productivity of sugarcane cultivation (YIREFU et al., 2012). For this reason, proper weed management is crucial for profitability in this agricultural segment.

Chemical control is the most suitable measure for weed control due to its practicality, efficiency, extensive size of the cultivation areas and lower cost compared to other control methods (BARELA; CHRISTOFFOLETI, 2006). Galon et al. (2012) have reported higher sugarcane productivity yields with herbicides as compared to manual weeding.

Knowing the environmental destination of herbicides is essential for assessing their risks. Knowledge of the processes involved between the interaction of herbicides and the soil is of fundamental importance in order to minimize negative effects on the environment, especially water resources (BERGSTRÖM; BÖRJESSON; STENSTRÖM, 2011; PINHEIRO; MORAES; SILVA, 2011). Therefore, when herbicides are applied in the soil, they are exposed to the environment and may biodegrade due to the influence of physical, chemical and biological factors, or volatilized, adsorbed by soil colloids determining the residual effect and transported externally by soil surface runoff and leaching (LI et al., 2003; ANDREU; PICÓ, 2004; GUNASEKARA et al., 2007; VRYZAS; PAPADAKIS; PAPADOPOULOU-MOURKIDOU, 2012).

In this way, the leaching process is related to the descendent movement, in other words, the carrying herbicides in the soil matrix or water in the soil. The intensity of this process depends on the physicalchemical characteristics of the product, such as high solubility and low octanol-water partition coefficient (Kow) of amicarbazone (CARVALHO et al., 2012), as well as the characteristics of the soil and water. The residual effect corresponds to the permanence of the herbicides in soil, which may contaminate the environment and lead to crop phytotoxicity (SOLTANI et al., 2011).

Among the herbicides registered for sugarcane cultivation in Brazil, amicarbazone is listed for controlling mono and dicotyledonous weeds. Amicarbamazone belongs to the chemical group triazolinone, which has systemic herbicide action against weeds, causing chlorosis, reduced growth, tissue necrosis and death of sensitive plants (DAYAN; TRINDADE; VELINI, 2009).

Amicarbamazone is used in pre and postemergence of plants, with its main action mechanism being the inhibition of photosynthesis, acting on the Hill reaction (photosystem II) by inhibiting electron transport and paralyzing $\mathrm{CO}_{2}$ fixation and ATP and $\mathrm{NADPH}_{2}$ production, which are essential for plant growth (ARALDI et al., 2011; PERRY; MCELROY; WALKER, 2011). This herbicide presents its formulation in granules that may be dispersed in water. The granules present high water solubility (4.6 $\mathrm{g} \mathrm{L}^{-1}$ at a $\mathrm{pH} 4.9$ ) and low vapor pressure $\left(1.3 \times 10^{-6} \mathrm{~Pa}\right.$ at $\left.20{ }^{\circ} \mathrm{C}\right)$ (CAVENAGHI et al., 2007). Since this herbicide is a new product on the market, information is limited regarding its translocation and behavior in the environment.

In order to study the activity of herbicide molecules in soils, several researchers have used bioassays, which are inexpensive, fast and precise. 
This technique uses plants sensitive to tested herbicides, in a way that herbicide residues present in the soil are evidenced by means of alteration related to agronomic characteristics of the test-plant (MONQUERO et al., 2008; BLANCO; VELINI; BATISTA FILHO, 2010).

This work aimed to evaluate the leaching potential and the residual effect of the herbicide amicarbazone, using soil columns under different simulations of pluvial precipitation and bioindicators sensitive to herbicides, respectively, in two soil types with contrasting textures.

\section{Materials and Methods}

Area of study

The experiments were done in a greenhouse in the county of Tangará da Serra, Mato Grosso State (MT), Brazil, with an area located on highway MT $358, \mathrm{~km} 07$ during 2012. Soil samples were collected in the counties of Campo Novo do Parecis and Tangará da Serra, MT, in order to obtain soils with contrasting characteristics. Soils were classified as quartzarenic neosoil (NR - sandy texture) from Campo Novo do Paress and as red latosol soil (LR - clay texture) from Tangará da Serra (EMBRAPA, 2006). Their physical-chemical characteristics are described in Table 1. Samples were collected at depths of 5 and $10 \mathrm{~cm}$. The soil was sieved to remove mulch and air dried for 24 hours.

Table 1. Physical-chemical characteristics of the soil samples used in the experiments.

\begin{tabular}{|c|c|c|c|c|c|c|c|}
\hline \multirow{2}{*}{ Soil } & \multicolumn{2}{|c|}{ pH } & \multirow[t]{2}{*}{$\mathbf{A l}^{3+}$} & \multirow[t]{2}{*}{$\mathbf{H}^{+}+\mathbf{A} \mathbf{l}^{3+}$} & \multirow{2}{*}{$\begin{array}{c}\mathrm{Ca}^{2+}+\mathrm{Mg}^{2+} \\
\left(\mathrm{cmol}_{\mathbf{c}} \mathbf{d m}^{-3}\right)\end{array}$} & \multirow[t]{2}{*}{$\mathrm{Ca}^{2+}$} & \multirow[t]{2}{*}{$\mathbf{K}^{+}$} \\
\hline & $\left(\mathrm{CaCl}_{2}\right)$ & $\left(\mathrm{H}_{2} \mathrm{O}\right)$ & & & & & \\
\hline $\mathrm{NR}^{1 /}$ & 7.1 & 7.8 & 0 & 1.13 & 2.75 & 2.19 & 0.02 \\
\hline $\mathrm{LR}^{2 /}$ & 5.8 & 6.7 & 0 & 3.13 & 6.00 & 4.31 & 0.37 \\
\hline \multirow{2}{*}{$\begin{array}{c}P \\
\left(\mathrm{mg} \mathrm{dm}^{-3}\right)\end{array}$} & \multirow{2}{*}{\multicolumn{2}{|c|}{$\begin{array}{c}\mathrm{C} \\
\left(\mathrm{g} \mathrm{dm}^{-3}\right) \\
\end{array}$}} & \multirow{2}{*}{$\begin{array}{c}\text { CTC } \\
\left(\mathrm{cmol}_{\mathrm{c}} \mathrm{dm}^{-3}\right)\end{array}$} & \multirow{2}{*}{$\begin{array}{c}\mathrm{V} \\
(\%) \\
\end{array}$} & Sand & Silt & Clay \\
\hline & & & & & \multicolumn{3}{|c|}{$\left(\mathrm{g} \mathrm{kg}^{-1}\right)$} \\
\hline 46.8 & \multicolumn{2}{|c|}{15} & 3.9 & 71 & 908 & 32 & 60 \\
\hline 2.3 & \multicolumn{2}{|c|}{43} & 9.0 & 67 & 415 & 147 & 438 \\
\hline
\end{tabular}

$\mathrm{NR}^{1}{ }^{1 /}=$ Quartzarenic Neosol (sandy texture); $\mathrm{LR}^{2} /=$ Red Latosol (clay texture).

Source: Laboratório de Solos Plante Certo, Várzea Grande, Mato Grosso State, Brazil.

Amicarbazone was applied to the top of the columns and at the upper edges of the columns and vases, keeping $50 \mathrm{~cm}$ between the upper edge and the application bar, according to the recommended doses for each type of soil (RODRIGUES; ALMEIDA, 2011). All herbicide applications were done at temperatures below $35{ }^{\circ} \mathrm{C}$ with a relative humidity over $60 \%$ using a $\mathrm{CO}_{2}$-pressurized sprayer with Flat Spray Tips XR 110.02. All applications used a spray volume equivalent to $200 \mathrm{~L} \mathrm{ha}^{-1}$ and a work pressure of $2 \mathrm{kgf} \mathrm{cm}^{-2}$.

\section{Leaching potential}

The leaching potential was assessed using soil columns. PVC columns (with a $30 \mathrm{~cm}$ height and $10 \mathrm{~cm}$ diameter) were paraffined internally for waterproofing. The bottom of each column was sealed with sombrite (a monofilament screen) for soil retention. After preparing the soil samples in columns, they were humidified in water by capillarity for $24 \mathrm{~h}$. Following this, the columns were maintained on the greenhouse counter for an additional $24 \mathrm{~h}$ to drain excess water. The herbicide amicabazone was applied 
(NR $1.05 \mathrm{~kg} \mathrm{ha}^{-1}$ and LR $1.40 \mathrm{~kg} \mathrm{ha}^{-1}$ ) according to the recommended doses for each soil type at the top of the columns (RODRIGUES; ALMEIDA, 2011). Precipitation in the amounts of 20,40, 60, 80 and $100 \mathrm{~mm}$ was simulated, as well as a control (zero $\mathrm{mm})$.

Two experiments were done, using NR or LR soil, in a $6 \times 6$ factorial design. The studied factors were simulated precipitation $(0,20,40,60,80$ and $100 \mathrm{~mm})$ and column depth $(0-5 ; 5-10 ; 10-15 ; 15-$ $20 ; 20-25 ; 25-30 \mathrm{~cm})$. The randomized block design with four replications was used in all experiments.

Twenty four hours after application, the columns were cut longitudinally. Following this, the bioindicator species (Cucumis sativus) was seeded along the columns. The soil columns were irrigated daily in order to maintain favorable plant growth conditions. Twenty one days after seeding (DAS), samples from each column section were selected ( 0 5 ; 5-10; 10-15; 15-20; 20-25; 25-30 cm) and placed in paper bags that were plaed in a forced ventilation oven at $48{ }^{\circ} \mathrm{C}$ for $72 \mathrm{~h}$ to determine the dry biomass.

Data was submitted to ANOVA and mean values were compared using the Scott-Knott test ( $p>0.05$ ).

\section{Residual effect}

In order to determine the residual effect, soil samples were prepared in plastic pots with a capacity of $5 \mathrm{dm}^{3}$. One soil type (NR or LR) was used in each experiment, distributed according to a randomized block design, $2 \times 5$ factorial, with four repetitions. The factors studied were doses and time period between herbicide application and the seeding of the bioindicator species $(0,25,50,75$ and 100 days after application (DAA) of herbicide). The doses of amicarbazone (NR $1.05 \mathrm{~kg} \mathrm{ha}^{-1}$ and LR $1.40 \mathrm{~kg} \mathrm{ha}^{-1}$ ) used were according to the recommendation in preemergent situations for soils with sandy and clay textures, respectively (RODRIGUES; ALMEIDA, 2011), tested on both soil types.
Ten seeds of the bioindicator species (Cucumis sativus) were seeded at $0,25,50,75$ and 100 DAA, with a depth of $1 \mathrm{~cm}$. Precipitation equivalent to the historical average over ten years was simulated in the periods between the herbicide applications and the seeding bioindicator for the Tangará da SerraMT region (MARTINS et al., 2010). After seeding, the pots were maintained with daily irrigation for 45 days. At the same time, the aerial parts of the bioindicator plants were separated and placed in paper bags, then placed in a forced ventilation oven at $40{ }^{\circ} \mathrm{C}$ for $72 \mathrm{~h}$ for dry biomass determination.

Obtained data were compared to the control (dosage of $0 \mathrm{~kg} \mathrm{ha}^{-1}$ ) and transformed in percentage of dry biomass inhibition. Results were subjected to ANOVA and regression adjustment ( $p>0.05)$.

\section{Results and Discussion}

\section{Leaching potential}

In the samples of NR (sandy texture), the movement of amicarbizone was more marked as a result of the depth of the irrigation water (Table 2 ), since $C$. sativus plants died on the entire column starting from the $60 \mathrm{~mm}$ irrigation depth. Moreover, total control of plants was observed up to a soil depth of 5-10 when a $20 \mathrm{~mm}$ irrigation depth was used and $10-15 \mathrm{~cm}$ with a $40 \mathrm{~mm}$ irrigation depth (Table 2).

In this way, the herbicide amicarbizone presented high leaching potential in sandy soils, where it can move across the soil profile, and even diminish the product efficiency in the control of weeds present in the first centimeters of the soil surface. On the other hand, small amounts of leaching may contribute to the improvement of weeds. This was noticed by Negrisoli et al. (2007), who verified the excellent control of $1.40 \mathrm{~kg} \mathrm{ha}^{-1}$ of amicarbazone on Brachiaria plantaginea, B. decumbens and Ipomoea grandifolia after $2.5 \mathrm{~mm}$ rain simulation. 
Table 2. Accumulation of dry biomass (mg section column ${ }^{-1}$ ) of the above ground part of Cucumis sativus plants cultivated in samples of Quartzarenic Neosol, from columns subjected to amicarbazone application (1.05 $\left.\mathrm{kg} \mathrm{ha}^{-1}\right)$

\begin{tabular}{|c|c|c|c|c|c|c|c|c|c|c|c|c|}
\hline \multirow{3}{*}{$\begin{array}{c}\text { Column depth } \\
\text { (cm) }\end{array}$} & \multicolumn{12}{|c|}{ Applied depth (mm) } \\
\hline & \multicolumn{2}{|c|}{$\mathbf{0}$} & \multicolumn{2}{|c|}{20} & \multicolumn{2}{|c|}{40} & \multicolumn{2}{|c|}{60} & \multicolumn{2}{|c|}{80} & \multicolumn{2}{|c|}{100} \\
\hline & 5.0 & $\mathrm{Ba}$ & 0.0 & $\mathrm{Ca}$ & 0.0 & $\mathrm{Ba}$ & 0.0 & $\mathrm{Aa}$ & 0.0 & $\mathrm{Aa}$ & 0.0 & $\mathrm{Aa}$ \\
\hline 5-10 & 320.0 & $\mathrm{Aa}$ & 0.0 & $\mathrm{Cb}$ & 0.0 & $\mathrm{Bb}$ & 0.0 & $\mathrm{Ab}$ & 0.0 & $\mathrm{Ab}$ & 0.0 & $\mathrm{Ab}$ \\
\hline $10-15$ & 327.5 & $\mathrm{Aa}$ & 250.0 & $\mathrm{Bb}$ & 0.0 & $\mathrm{Bc}$ & 0.0 & Ac & 0.0 & Ac & 0.0 & Ac \\
\hline $15-20$ & 350.0 & $\mathrm{Aa}$ & 300.0 & $\mathrm{Ab}$ & 305.0 & $\mathrm{Ab}$ & 0.0 & Ac & 0.0 & Ac & 0.0 & Ac \\
\hline $20-25$ & 327.5 & Aa & 315.0 & $\mathrm{Aa}$ & 302.5 & Aa & 0.0 & $\mathrm{Ab}$ & 0.0 & $\mathrm{Ab}$ & 0.0 & $\mathrm{Ab}$ \\
\hline $25-30$ & 340.0 & Aa & 332.5 & $\mathrm{Aa}$ & 307.5 & $\mathrm{Ab}$ & 0.0 & Ac & 0.0 & $\mathrm{Ac}$ & 0.0 & Ac \\
\hline
\end{tabular}

The averages followed by the same uppercase letter in the row and lowercase in the column did not differ according to the ScottKnott test at $5 \%$ probability. C.V. $=18.41 \%$.

Source: Elaboration of the authors.

In soil with medium texture (10-13 $\mathrm{g} \mathrm{dm}^{-3}$ of organic matter and $27-29 \%$ clay), Bachega et al. (2009) obtained results for the herbicide amicarbazone applied to post-emergent weeds with $67 \mathrm{~mm}$ precipitation, showing marked reduction of dry matter of Common Morning Glory (Ipomoea nil) at a depth of 0.0-2.5 cm when mineral oil was added to the herbicide. The mineral oil kept the herbicide in the most superficial layer of the soil. However, $106 \mathrm{~mm}$ of simulated rain resulted in herbicide total leaching $(0.0-35.0 \mathrm{~cm})$ and the oil had no effect in herbicide retention.

For the LR samples (clay texture), an irrigation depth of 20 to $80 \mathrm{~mm}$ water reduced biomass 5-10 $\mathrm{cm}$ depth in soil columns (Table 3.) However, the biomass of $C$. sativus was reduced by $10-15 \mathrm{~cm}$ (Table 3) in the columns that received $100 \mathrm{~mm}$ of water. This evidenced the leaching of amicarbizone molecules up to that depth.

Table 3. Accumulation of dry biomass ( $\mathrm{mg} \mathrm{section} \mathrm{column}^{-1}$ ) of the above ground portion of plants of Cucumis sativus cultivated in samples of Red Latosol, from columns subjected to amicarbazone application $\left(1.40 \mathrm{~kg} \mathrm{ha}^{-1}\right)$.

\begin{tabular}{|c|c|c|c|c|c|c|c|c|c|c|c|c|}
\hline \multirow{3}{*}{$\begin{array}{c}\text { Column depth } \\
\text { (cm) }\end{array}$} & \multicolumn{12}{|c|}{ Applied depth (mm) } \\
\hline & \multicolumn{2}{|l|}{ 0 } & \multicolumn{2}{|c|}{20} & \multicolumn{2}{|c|}{40} & \multicolumn{2}{|c|}{60} & \multicolumn{2}{|c|}{80} & \multicolumn{2}{|c|}{100} \\
\hline & 25.0 & $\mathrm{Ba}$ & 5.0 & $\mathrm{Ca}$ & 40.0 & $\mathrm{Ca}$ & 0.0 & $\mathrm{Ba}$ & 0.0 & $\mathrm{Ba}$ & 0.0 & $\mathrm{Ca}$ \\
\hline 5-10 & 305.0 & $\mathrm{Aa}$ & 225.0 & $\mathrm{Ba}$ & 225.0 & $\mathrm{Ba}$ & 27.5 & $\mathrm{Bb}$ & 25.0 & $\mathrm{Bb}$ & 5.0 & $\mathrm{Cb}$ \\
\hline $10-15$ & 340.0 & $\mathrm{Aa}$ & 322.5 & $\mathrm{Aa}$ & 287.5 & $\mathrm{Ab}$ & 297.5 & $\mathrm{Ab}$ & 290.0 & $\mathrm{Ab}$ & 260.0 & $\mathrm{Bb}$ \\
\hline $15-20$ & 340.0 & Aa & 312.5 & $\mathrm{Aa}$ & 312.5 & $\mathrm{Aa}$ & 310.0 & $\mathrm{Aa}$ & 307.5 & $\mathrm{Aa}$ & 300.0 & $\mathrm{Aa}$ \\
\hline $20-25$ & 315.0 & $\mathrm{Aa}$ & 310.0 & $\mathrm{Aa}$ & 327.5 & $\mathrm{Aa}$ & 310.0 & $\mathrm{Aa}$ & 297.5 & $\mathrm{Aa}$ & 320.0 & $\mathrm{Aa}$ \\
\hline $25-30$ & 315.0 & $\mathrm{Aa}$ & 320.0 & $\mathrm{Aa}$ & 325.0 & $\mathrm{Aa}$ & 323.5 & $\mathrm{Aa}$ & 310.0 & $\mathrm{Aa}$ & 332.5 & $\mathrm{Aa}$ \\
\hline
\end{tabular}

The average followed by the same capital letter in the column and lowercase letter in the row did not differ according to the ScottKnott test at $5 \%$ probability. C.V. $=13.72 \%$.

Source: Elaboration of the authors. 
Based on these results we conclude that amicarbazone presented higher leaching potential when applied to sandy soils than in clay soils. This can be attributed to high levels of clay (43.8\%) and organic carbon $\left(43 \mathrm{~g} \mathrm{dm}^{-3}\right)$ in soils with clay texture. These characteristics provide higher water retention capacity, preventing the tested herbicide from leaching completely. Herbicides tend to present higher leaching indexes due to pluvial precipitations or artificial irrigations, with marked effects in soils with medium texture and lower levels of organic matter (MONQUERO et al., 2008; ANDRADE et al., 2010). In sandy soils, the leaching will be even higher than in clay or silty soils (ROSSI; ALVES; MARQUES JUNIOR, 2005).

Cavenaghi et. al. (2007) evaluated the dynamic of amicarbazone applied to different quantities of straw sugarcane at different time intervals and rain intensities after herbicide application. Results showed that the amount of amicarbizone leached by the applied water irrigation depth varied according to the used straw $\left(5,10,15\right.$ and $\left.20 \mathrm{tha}^{-1}\right)$. For $5 \mathrm{t}$ ha $^{-1}$ of straw, a $2.5 \mathrm{~mm}$ irrigation depth leached $40 \%$ of applied amicarbazone, while for 10, 15 and $20 \mathrm{t}$ $\mathrm{ha}^{-1}$ of straw the same irrigation depth leached 33 , 25 and $25 \%$ of applied amicarbazone, respectively. This means that straw intensities equal or greater than $5 \mathrm{t} \mathrm{ha}^{-1}$ presented significant interception of the herbicide at the application time, thus reducing amicarbizone transposition. The effect of the first irrigation depth on the leaching process for each amount of straw was more intense, removing higher amounts of the herbicide from the straw compared to the final irrigation depth, in which the process was mitigated.

\section{Residual effect}

Figure 1 indicates the results of controls obtained after the use of amicabazone in soils with clay and sandy textures.

The amicarbazone applied directly to the soil with clayey texture provided a control above $80 \%$ up to 100 DAA, in both doses (Figure 1). Hence, these data indicate that the reduction of amicarbazone doses is possible without affecting the residual. In soil with mean texture (15 to $35 \%$ clay), when amicarbazone was applied (1.4 $\left.\mathrm{kg} \mathrm{ha}^{-1}\right)$ in pre-emergence, Negrisoli et al. (2007) observed excellent control (above 90\%) of $B$. decumbens at $14,21,28,35,42,49$ and 56 DAA.

In the soil with sandy texture, the control was above $80 \%$ only until 51 DAA, independent of the applied doses. This may be attributed to the leaching potential of the herbicide in sandy soil, due to the high solubility of the herbicide molecule $\left(4.6 \mathrm{~g} \mathrm{~L}^{-1}\right.$ at $\mathrm{pH} 4.9$ ). In quartzarenic neosol the characteristics of low levels of clay and organic carbon may have reduced herbicide molecule retention, favoring herbicide leaching and a diminished residual effect. Sorption can diminish the efficacy of herbicides in the soil, influencing its bioavailability and susceptibility to leaching (YANG; SHENG, 2003; LOGANATHAN et al., 2009). However, molecule retention is reduced in soils with low levels of clay and organic matter, favoring the leaching (FERRI et al. 2002; CORREIA; LANGENBACH, 2006; ALLETTO et al., 2010). Also, the pH of quartzarenic neosol (7.8) may have influenced the higher leaching of the herbicide, since Oliveira, Prates and Sans (2005) verified that higher soil $\mathrm{pH}$ values reduced herbicide sorption, indicating a reduced residual effect. 
Figure 1. Percentage of inhibition in the accumulation of dry biomass in Cucumis sativus, at 0, 25, 50, 75 and 100 days after the application of amicarbazone. A) Red Latosol and amicarbazone at the dose of $1.40 \mathrm{~kg} \mathrm{ha}^{-1}$; B) Red Latosol and amicarbazone at a dose of $1.05 \mathrm{~kg} \mathrm{ha}^{-1}$; C) Quartzarenic Neosol and amicarbazone at the dose of $1.40 \mathrm{~kg} \mathrm{ha}^{-1}$; D) Quartzarenic Neosol and amicarbazone at the dose of $1.05 \mathrm{~kg} \mathrm{ha}^{-1}$.

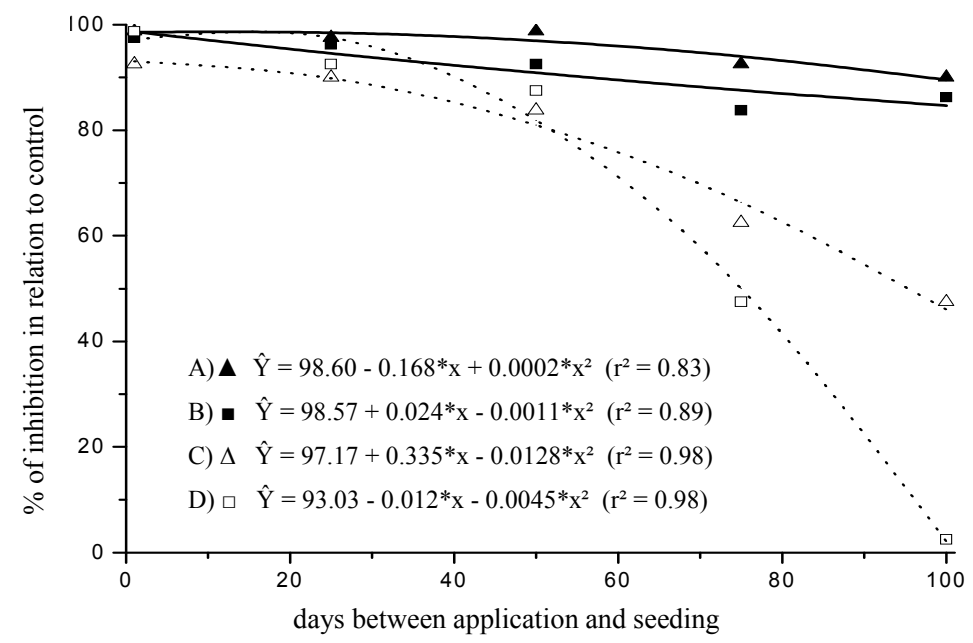

Source: Elaboration of the authors.

Based on these results, it is possible to conclude that soil samples with sandy texture provided higher effective movement of amicarbazone molecules compared to soils with clay texture. In general, amicarbazone presented higher residual effects on soil samples with clay texture, independent of the applied dose. Thus, there is a possibility of working with lower doses of amicarbazone in clay soils, without producing a residual effect. On the other hand, the increased dose of amicarbazone in soil samples of clay texture significantly augmented the residual effects of the herbicide. the residual effect of the herbicide.

\section{References}

ALLETTO, L.; COQUET, Y.; BENOIT, P.; HEDDADJ, D.; BARRIUSO, E. Tillage management effects on pesticide fate in soils. A review. Agronomy for Sustainable Development, Les Ulis Cedex, v. 30, n. 2, p. 367-400, 2010.

ANDRADE, S. R. B.; SILVA, A. A.; LIMA, C. F.; D'ANTONINO, L.; QUEIROZ, M. E. L. R.; FRANÇA, A. C.; FELIPE, R. S.; VICTORIA FILHO, R. Lixiviação do ametryn em argissolo vermelho-amarelo e latossolo vermelho-amarelo, com diferentes valores de $\mathrm{pH}$. Planta Daninha, Viçosa, v. 28, n. 3, p. 655-663, 2010.
ANDREU, V.; PICÓ, Y. Determination of pesticides and their degradation products in soil: critical review and comparison of methods. Trends in Analytical Chemistry, Amsterdam, v. 23, n. 10-11, p. 772-789, 2004.

ARALDI, R.; VELINI, E. D.; GIROTTO, M.; CARBONARI, C. A.; JASPER, S. P.; TRINDADE, M. L. B. Efeitos na taxa de transporte de elétrons de plantas daninhas após aplicação de amicarbazone. Planta Daninha, Viçosa, v. 29, n. 3, p. 647-653, 2011.

BACHEGA, T. F.; PAVANI, M. C. M. D.; ALVES, P. L. C. A.; SAES, L. P.; BOSCHIERO, M. Lixiviação de sulfentrazone e amicarbazone em colunas de solo com adição de óleo mineral. Planta Daninha, Viçosa, v. 27, n. 2, p. 363-370, 2009.

BARELA, J. F.; CHRISTOFFOLETI, P. J. Seletividade de herbicidas aplicados em pré-emergência da cultura da cana-de-açúcar (RB867515) tratada com nematicidas. Planta Daninha, Viçosa, v. 24, n. 2, p. 371-378, 2006.

BERGSTRÖM, L.; BÖRJESSON, E.; STENSTRÖM, J. Laboratory and lysimeter studies of glyphosate and aminomethylphos-phonic acid in a sand and clay soil. Journal of Environmental Quality, Madison, v. 40, n. 1, p. 98-108, 2011.

BLANCO, F. M. G.; VELINI, E. D.; BATISTA FILHO, A. Persistência do herbicida sulfentrazone em solo cultivado com cana-de-açúcar. Bragantia, Campinas, v. 69, n. 1, p. 71-75, 2010. 
CARVALHO, S. J. P.; DIAS, A. C. R.; MINAMIGUCHI, M. H.; NICOLAI, M.; CHRISTOFFOLETI, P. J. Atividade residual de seis herbicidas aplicados ao solo em época seca. Revista Ceres, Viçosa, v. 59, n. 2, p. 278285, 2012.

CAVENAGHI, A. L.; ROSSI, C. V. S.; NEGRISOLI, E.; COSTA, E. A. D.; VELINI, E. D.; TOLEDO, R. E. B. Dinâmica do herbicida amicarbazone (dinamic) aplicado sobre palha de cana-de-açúcar (Saccarum officinarum). Planta Daninha, Viçosa, v. 25, n. 4, p. 831-837, 2007.

CORREIA, F. V.; LANGENBACH, T. Dinâmica da distribuição e degradação de atrazina em argissolo Vermelho-Amarelo sob condições de clima tropical úmido. Revista Brasileira de Ciência do Solo, Viçosa, v. 30, n. 1, p. 183-192, 2006.

DAYAN, F. E.; TRINDADE, M. L. B.; VELINI, E. D. Amicarbazone, a new photosystem II inhibitor. Weed Science, Champaign, v. 57, n. 6, p. 579-583, 2009.

EMPRESA BRASILEIRA DE PESQUISA AGROPECUÁRIA - EMBRAPA. Centro Nacional de Pesquisa de Solos. Sistema brasileiro de classificação de solos. 2. ed. Rio de Janeiro: Embrapa Solos, 2006. 306 p.

FERRI, M. V. W.; VIDAL, R. A.; GOMES, J.; DICK, D. P.; SOUZA, R. F. Atividade do herbicida acetochlor em solo submetido à semeadura direta e ao preparo convencional. Pesquisa Agropecuária Brasileira, Brasília, v. 37, n. 12, p. 1697-1703, 2002.

GALON, L.; TIRONI, S. P.; SILVA, A. A.; SILVA, A. F.; CONCENÇO, G.; ROCHA, P. R. R.; KUNZ, V. L.; FERREIRA, E. A.; FERREIRA, F. A. Eficiência de controle de Brachiaria brizantha e seletividade dos herbicidas $\{$ (diuron + hexazinone) + MSMA $\}$ aplicados à cultura da cana-de-açúcar. Planta Daninha, Viçosa, v. 30, n. 2, p. 367-376, 2012.

GUNASEKARA, A. S.; TROIANO, J.; GOH, K. S.; TJEERDEMA, R. S. Chemistry and Fate of Simazine. Reviews of Environmental Contamination and Toxicology, Summerfield, v. 189, p. 1-23, 2007.

LI, H.; SHENG, G.; TEPPEN, B. J.; JOHNSTON, C. T.; BOYD, S. A. Sorption and desorption of pesticides by clay minerals and humic acid-clay complexes. Soil Science Society of America Journal, Madison, v. 67, n. 1, p. 122-131, 2003.

LOGANATHAN, V. A.; FENG, Y.; SHENG, G. D.; CLEMENT, T. P. Crop-residue-derived char influences sorption, desorption and bioavailability of atrazine in soils. Soil Science Society of America Journal, Madison, v. 73, n. 3, p. 967-974, 2009.

MARTINS, J.A.; DALLACORT, R.; INOUE, M.H.; SANTI, A.; KOLLING, E. M.; COLETTI, A. J. Probabilidade de precipitação para a microrregião de Tangará da Serra, Estado do Mato Grosso. Pesquisa Agropecuária Tropical, Goiânia, v. 40, n. 3, p. 291-296, 2010.

MONQUERO, P. A.; BINHA, D. P.; AMARAL, L. R.; SILVA, P. V.; SILVA, A. C.; INACIO, E. M. Lixiviação de clomazone + ametryn, diuron + hexazinone e isoxaflutole em dois tipos de solo. Planta Daninha, Viçosa, v. 26, n. 3, p. 685-691, 2008.

NEGRISOLI, E.; ROSSI, C. V. S.; VELINI, E. D.; CAVENAGHI, A. L.; COSTA, E. A. D.; TOLEDO, R. E. B. Controle de planta daninha pelo amicarbazone aplicado na presença de palha da cana-de-açúcar. Planta Daninha, Viçosa, v. 25, n. 3, p. 603-611, 2007.

OLIVEIRA, M. F.; PRATES, H. T.; SANS, L. M. A. Sorção e hidrólise do herbicida flazasulfuron. Planta Daninha, Viçosa, v. 23, n. 1, p. 101-113, 2005.

PERRY, D. H.; MCELROY, J. S.; WALKER, R. H. Effects of Soil vs. Foliar Application of Amicarbazone on Annual Bluegrass (Poa annua). Weed Technology, Champaign, v. 25, n. 4, p. 604-608, 2011.

PINHEIRO, A.; MORAES, J. C. S.; SILVA, M. R. Pesticidas no perfil do solo em áreas de plantação de cebolas em Ituporanga, SC. Revista Brasileira de Engenharia Agrícola e Ambiental, Campina Grande, v. 15 , n. 5, p. 533-538, 2011.

RODRIGUES, B. N.; ALMEIDA, F. S. Guia de herbicidas. 6. ed. Londrina: IAPAR, 2011. 697 p.

ROSSI, C. V. S.; ALVES, P. L. C. A.; MARQUES JUNIOR, J. Mobilidade do sulfentrazone em latossolo vermelho e em chernossolo. Planta Daninha, Viçosa, v. 23 , n. 4, p. 701-710, 2005.

SOLTANI, N.; MASHHADI, R. H.; MESGARAN, M. B.; COWBROUGH, M.; TARDIF, F. J.; CHANDLER, K.; SWANTON, C. J.; SIKKEMA, P. $\mathrm{H}$. The effect of residual corn herbicides on soybean injury and yield seeded in the same season. Canadian Journal of Plant Science, Quebec, v. 91, n. 3, p. 571576, 2011.

VRYZAS, Z.; PAPADAKIS, E. N.; PAPADOPOULOU-MOURKIDOU, E. Leaching of $\mathrm{Br}$, metolachlor, alachlor, atrazine, deethylatrazine and deisopropylatrazine in clayey vadoze zone: a field scale experiment in north-east Greece. Water Research, Oxford, v. 46, n. 6, p. 1979-1989, 2012.

YANG, Y. N.; SHENG, G. Y. Pesticide adsorptivity of aged particulate matter arising from crop residue burns. Journal of Agricultural and Food Chemistry, Washington, v. 51, n. 17, p. 5047-5051, 2003.

YIREFU, F.; TANA, T.; TAFESSE, A.; ZEKARIAS, Y. Competitive ability of sugarcane (Saccharum officinarum L.) cultivars to weed interference in sugarcane plantations of Ethiopia. Crop Protection, Guildford, v. 32, n. 6, p. 138-143, 2012. 